\title{
Information
}

Article

https://dx.doi.org/10.4314/iijikm.v9i4.6

Impact

\section{Reinvigorating Library and Information \\ Science (LIS) Curriculum in a Fast Changing Society}

Gideon A. Babalola

Federal University of Technology Minna, Niger State, Nigeria

Saba Mohammed Adamu

Federal University of Technology Minna, Niger State, Nigeria

Kingsley Olawale Aji

College of Education, FCT, Zuba, Abuja

Abubakar Fati

Federal University ofTechnology, Minna, Niger State. Nigeria

Musa Imam Shekarau

Federal University of Technology, Minna, Niger State. Nigeria
Information Impact: Journal

of information and

knowledge management

2018, Vol. 9 (4) Pg 63-72

ISSN: $2141-4297$ (print)

ISSN: 2360 - 994X (e-version)

\begin{abstract}
This paper discussed the need for reinvigorating Library and Information Science (LIS) curriculum in a fast changing society. Reinvigorating LIS curriculum is not only a necessity but mandatory if the prospective LIS graduates would be employers of labour rather than job seekers in a continuously fast changing society of the $21^{\text {st }}$ century. To train LIS students in entrepreneurship requires the development of a comprehensive but dynamic curriculum that responds to changing needs in the field. The implementation of this curriculum will enable beneficiaries to be self-employed by carrying out such entrepreneurial activities like abstracting, indexing, publishing, database development and management, collection management, knowledge management, organization of knowledge, current awareness services, staff recruitment and development, conduct of researches, bibliographic and metadata searching, journals and book business, material conservation and preservation, generation of ideas, etcetera.
\end{abstract}

Keywords: Curriculum, Information Science, Library science, Infoprenuership, profession

\section{Introduction}

Reinvigorating Library and Information Science (LIS) curriculum for enhanced job opportunities is not only a necessity but mandatory in this rapidly changing society. The need to infuse life giving ingredients into LIS curriculum in the information age cannot be over emphasised. The $21^{\text {st }}$ century is characterized with: stiff competition in the information/labour market; dwindling job opportunities; general economic recession, ubiquitous unrest, unemployment and prevalent global hunger amongst others. There is the urgent need for library schools in Nigeria and across the globe to produce graduates who would be able to cope with the exigencies and the unpleasant scenarios that are rapidly unfolding in information/labour market of the digital age. One of the major avenues by which library schools would be able to achieve this mission is through the reinvigoration of LIS curriculum. Graduates from library schools 
should be trained to be self reliant, creative, innovative, productive and becoming job creators rather than job seekers in this information driven age. Adequate attention should be given to: entrepreneurial oriented, information broking services, publishing, book trade and a good number of other information related courses. A pragmatic way of reducing poverty and youth restiveness in Nigeria and globally is by ensuring that all able-bodied, qualified, skilful young men and women are gainfully employed. People that are employed are assets in any economy. Rather than operating as mere consumers of what others are producing, they are zealously engaged in contributing their own significant quota in form of per capita income to the economy.

Education is the process of imparting knowledge, skills and judgment into the learners or individuals. It is in a continuum and is seen as a lifelong process. There are informal and formal systems of education. The formal educational system in Nigeria has been organised into primary, secondary and tertiary education. Etim (2002) sees library and information science as the study of issues related to library and information services. Curriculum is the totality of the content of an area of study to be imparted to its intended learners. In its simplistic definition, the Websters Universal Dictionary and Thesaurus (2007) views curriculum as "a prescribed course of study. Lunenburg (2011) summarised curriculum experts' conceptions and definitions of the topic as the content of what is to be learned, the learning experiences, the behavioural objectives to be achieved, by bringing about the desired behaviours in the learners, the plan for instruction, and the non-technical approach, which include the aesthetic, pluralistic/diverse, spiritual, etcetra aspects of curriculum.

\section{Career Paths for LIS professionals}

Library and Information Science (LIS) professionals have a lot of potentials to develop the knowledge and skills required to sustain and survive in the present day knowledge society. Globalization and liberalization have opened up multiple career options to the LIS professionals. The traditional roles of LIS have changed with the advances in Information and Communication Technologies. LIS professionals are expected to be academics of higher order with competence to work in a hypertext, networked and digital environments. Hence, the LIS education should impart the learners with the necessary skills to gain employment upon graduation and to develop the vision and understanding to help them cope better with the rapidly changing world (Sinha \& Pandey, 2014). Nowadays, a number of career prospects are available in Library and Information Science. The qualified and trained professionals are employed in various libraries and information centres. LIS professionals can select the type of library as per their own interest. Thus, there is a very bright future prospect for LIS professional. It is only the trained personnel in LIS that can have employment opportunities in the various sectors (Unegbu \& Unuoha, 2013). Some of the available career paths in LIS profession includes: publishing, development of computer software, production and sales of library equipment, information brokerage, consultancy services, bookselling business, record manager, indexing and abstracting services, 
system analyst, operation of business centres and cybercafé business, editorial services, authoring books etcetera.

\section{Ingredients for reinvigorating LIS curriculum in a recessed economy}

Entrepreneurial education was introduced by the National Board for Technical Education in 2007 to help train entrerpreneurs in library related and non library related enterprises. Some of the entrepreneurial ventures in librarianship include: bookshop management; indexing and abstracting services; editing books and journals; records management; exhibitions; publishing and reprography; video recording; information brokerage; document screening and control feebased writing amongst others. In order to accentuate employment, reduce unemployment, underemployment, poverty and youth restiveness, entrepreneurship education was introduced as a compulsory course which is receiving global attention. Musa (2009) stated that indigenous entrepreneurship through provision of enabling environment, technical education and financial assistance as well as skill acquisition opportunities has been a cardinal thrust for employment generation. Aladekomo (2004) remarked that Nigeria policy on education emphasised the need for functional education that is relevant, practical and with particular emphasis on the acquisition of appropriate skills and development of competencies and equipment for the individuals to live in and contribute to the development of his/her society. Amoor (2008) stated that entrepreneurship education will provide the students with the opportunities to identify and develop a range of skills and attributes that will be of use to creating and shaping their future by experiencing both business and work environment. Nnadozie, Akanwa and Nnadozie (2013) revealed that diminishing job openings and exposure to entrepreneurship education should make the library and information science graduates explore the opportunities in other sectors where they can put their specialised training to their best advantage. Fakuade (2015) noted that entrepreneurship means ownership and self determination as opposed to simply being dependent on somebody else for one's livelihood and future. Effective entrepreneurial education is not possible without the right lecturers, students, supporting technology, laboratory equipment and allied infrastructures. Career paths for LIS students could be shaped and encouraged by entrepreneurial education provided. The information age no doubt provides the LIS students with contours of entrepreneurial options within and outside the library walls.

Today all Nigerian universities now offer one entrepreneur course called GST 311 at least theoretically, with very few having entrepreneurship centres where students could learn practical skills. Even among those with entrepreneurship centres, not all are equipped for the acquisition of practical skills. The zonal centres that were proposed have also not taken off. This position is supported by Dantani and Ibrahim (2014) who observed that the paucity of qualified instructors/teachers, instructional equipment/materials and well equipped laboratories are capable of frustrating entrepreneurial education in Nigeria. In a related development, Departments of Library and Information Science in Nigerian universities, have also come up with LIS-related entrepreneurial courses. A look at the course descriptions of about 25 approved 
LIS programmes in Nigerian universities indicates that entrepreneurship courses peculiar to the field are hardly offered presently, apart from the general studies course. Among the few LIS departments offering entrepreneurship courses, are those of Federal University of Technology, Minna, University of Ilorin, Ilorin; Ahmadu Bello University, Zaria; Babcock University, Ilishan, etcetera. The Federal University of Technology, Minna, for example offers LIT 524: Entrepreneurship in Library and Information Technology, LIT 324: Publishing and book trade; LIT 518: Information products and services, LIT 525: Electronic publishing and LIT 318: Data Communications and Network; LIT 319: Analysis and Design of Library Information Systems. The University of Ilorin offers LIS 402: Entrepreneurship in Information. In its justification for offering this course LIS 402, the institution stated that it is intended to circumvent unemployment of librarians in the public and private sectors, thus, encouraging prospective LIS graduates to be self employed and to create employment for others as well (University of Ilorin, 2014). The course content of LIS 402 is as follows:

1. Options, openings and possibilities for self employment, employment creation.

2. Requirements for establishing and managing enterprises.

3. Business plan project.

4. Introduction to small business start-up.

5. Identifying information business opportunities.

6. Lobbying, advocacy and fund raising for development of libraries and information centres.

7. Branding and marketing for changing the image of libraries.

However, in most of the twenty-five approved LIS Programmes in Nigerian Universities, there are a number of business-related courses, which are aimed at tuning (re-orienting) students' minds towards possible self-employment upon graduation. In Ahmadu Bello University, Zaria, for example, courses like LIS 220: Business Information Systems and Services; LIS 321: Marketing of Libraries and Information Centres; LIS 323: Financial Management in Libraries and Information Centres; and LIS 414: Publishing and Advertising are offered. In the University of Nigeria, Nsukka, LIS 448: Library Marketing and Public Relations is offered. At the Abubakar Tafawa Balewa University, Bauchi, the LIS Programme offers LIS 513: Library and Information Consultancy and LIS 523: Marketing of Library and Information Services. In the LIS Programme at the University of Abuja, such courses include LIS 302: Introduction to Publishing, LIS 408: Marketing Library and Information Services, LIS 409: Library and Information Consultancy, and LIS 411: Revenue Generation in Libraries and Information Centres. There is no doubt that there is growing awareness and need for entrepreneurship courses in Library and Information Science. This has led to increased literature in the area, for example, Igbeka (2008) and Issa et al. (2014) are among those that have produced materials in the field. This awareness has also been made possible by hosting of many conferences, workshops, etcetera, for example, the National Association of Library and Information Science Educators (NALISE) Conference on Entrepreneurship Education in Library and Information Science Programmes held at the Ahmadu Bello University, Zaria between 8th to 12th November, 2011. 
Other examples are the National Workshop on "Entrepreneurship in Librarianship", which was organized by the Librarians' Registration Council of Nigeria (LRCN) at Kuchukau in Nasarawa State between 29th July and 2nd August, 2013, and the Second International Conference of the School of Technology Education, Federal University of Technology, Minna with the theme: Innovation and Entrepreneurship in Science and Technology Education for Self-Reliance held between 12th to 15th October, 2014, amongst others. In furtherance of the need to entrench entrepreneurial studies in LIS curriculum at the undergraduate level, some experts who were invited by the NUC to review the existing Benchmark and Minimum Academic Standards (BMAS) and come up with a new one that would meet modern realities proposed for the inclusion of a course to be known as Infopreneurship, among several other new courses that were proposed. The proposed content of Infopreneurship subject to final approval by the NUC will contain such essential aspects such as:

1. Concept of Infopreneurship.

2. Need for Infopreneurship skills.

3. Income/Revenue Generation Activities in Libraries and Information Centres.

4. Techniques for Generating Income/Revenues.

5. Establishing and Managing Revenue Generating Activities.

6. Problems and Prospects of Revenue Generation Activities

\section{Reinvigorating LIS curriculum for enhancing Job opportunity in Nigeria Integrating Entrepreneurship in LIS curriculum}

The first step in reviving LIS curriculum in a recessed economy with the aim of alleviating poverty is to have a curriculum tailored towards entrepreneurship; of which most LIS departments have viable ones, at least in business related areas. However, the success or failure of these curricula in terms of whether the students internalize the values they are expected to imbibe with regard to entrepreneurship depends more on the implementation of such curricula. A good LIS curriculum should be comprehensive and dynamic to be responsive to changing needs in LIS. This is what the proposed course, Infopreneurship seeks to be (Ekoja and Odu, 2016).

\section{Proper orientation of students offering LIS courses}

Some students currently offering the General Studies Entrepreneurship merely see it as a requirement for graduation and not a means for developing their interest in entrepreneurship. The students from the outset should be convinced that they need it, they can do it, and require to hold on tenaciously to its principles; and savour the desire to be successful entrepreneurs notwithstanding likely obstacles on their path. Acknowledging the significance of the above, Bamkole (2007) advised that for students to be adequately prepared to face the challenges of venturing, it is important to counsel them to adopt attitudinal reorientation towards selfemployment and self-reliance. 


\section{Seminars and symposia by resource personnel}

To impart entrepreneurial skills in students, there is need to have qualified people who can handle both theoretical and practical aspects. This, preferably should be people who themselves have served as consultants or entrepreneurs, and whose consulting or entrepreneurship activities have kept them in touch with the business world. LIS Departments can also bring in entrepreneurs like the Managing Director of Havillah Books, to give talks on their experiences in terms of how they started, their doggedness in the face of obstacles, and how they have been able to weather the storm (Ekoja and Odu, 2016). Reference is made to Havillah Books because she is one of the most successful in book vending in Nigeria. Since much of information and library services revolve around ICTs, there is the need for requipping of LIS laboratories with full Internet connectivity, as well as other enabling facilities with which students can have hands-on experience. These laboratories should be made accessible to students for sufficient number of hours in a day, and if possible 24/7. One other way of gaining practical experience is through participating in the activities of Entrepreneurship in Action and Us (ENACTUS), which until October, 2012 was known as students in Free Enterprise (SIFE). Enactus is "a global non-profit and community of students, academics and business leaders committed to using the power of entrepreneurial action to transform lives (Enactus Nigeria, 2014).

\section{Promoting entrepreneurship education in LIS}

It is important to create and promote entrepreneurship awareness in LIS students and make students know the opportunities that exist in terms of the activities they can engage in, how to write viable business plans, the market(s) available and the regulations guiding operations in them as well as how to maximize the benefits of operating in them. This can also touch on how to overcome likely obstacles, including risk-taking. Another important aspect of implementing the curriculum in entrepreneurship education is to let the students know about existing market linkages and how to promote such linkages. For example, a student who is interested in book vending and journal subscription business upon graduation should have the contacts of local and overseas books and journals vendors and publishers that he/she would have beneficial relationship with for his/her intended business. It is important too that students should know about the sources from which they can access funding (loans, etc) with which to start the businesses they intend going into.

\section{Conclusion}

Reinvigorating LIS curriculum in a recessed economy with the ultimate goal of alleviating poverty in Nigerian tertiary institution requires pragmatic approach and sincere commitment on the part of all the stakeholders: the students, lecturers, technical staff, school management and government if the issue of unemployment must be surmounted. It is now about ten years that entrepreneurship education has been embraced as a compulsory General Studies course in most Nigerian universities with varying levels of successes. In most of the universities, this course is still taught only theoretically. In the few ones where there exist entrepreneurship centres, they are 
not well equipped with the requisite facilities and artisans to implement the impartation and acquisition of skills by students. Education managers must do the needful in providing the needed learning facilities and manpower that will impact positively on entrepreneurship skill acquisition capable of driving the needed jobs creation and economic development of the society. Nigeria current unemployment woe can be confronted frontally through a robust entrepreneurship education that is devoid of dilapidated or non existence of teaching facilities, personnel and laboratories. Despite the visible and long term benefits of entrepreneurship education, there are no requisite facilities capable of provoking the desired entrepreneurial spirit among library and information science students. It is apt to conclude that entrepreneurship education is the only ingredient for reviving LIS curriculum and remains the only potent economic arsenary and weaponry for combating unemployment and poverty in a recessed economy.

\section{Recommendations}

This paper, however, recommends the following:-

1. There is the need to provide state of the art printing machines, photocopiers, binding and lamination machines, Internet, and library digitiation softwares to drive the needed entrepreneurial skills in library related businesses to graduates of LIS.

2. There is the need for the use of various teaching methodologies such as students and lecturers centred practicals, trend analysis, market surveys and business proposals and memo writing.

3. Construction of entrepreneurship worshops, employment of additional qualified lecturers, improved funding, reduction of students in take and the adoption of innovative pedagogical strategies on the part of lecturers in LIS in teaching entrepreneurship are strongly recommended.

4. Government ought to create favourable environment in terms of infrastructure provision, funding and regulating interest rates on bank loans, etcetera.

\section{References}

Adejimola, A.S. \& Olufumilayo, T. (2009). Spinning off an entrepreneurship culture among Nigerian University Students; prospect and challenges African Journal of Business Management, 1 (3), $80-88$.

Aladekomo, F.O. (2004). Nigeria Educational Policy and Entrepreneurship. Journal of Social Science, 9 (2), $75-78$.

Amoor, S.S.(2008) Integrating Entrepreneurship Education Into Business Education Curriculum in Nigerian University. Zaria Journal of Libral Arts, 2 (2), 1 - 2. 
Atulomah, B. C.\& Onuoha, U. D. (2011). Harnessing Collective Intelligence Through Online Social Networks: A Study of Librarians in Private Universities in Ogun State, Nigeria Ozean Journal of Social Science, . 4 (2). Retrieved from http://www.ozelacademy.com/ojss_v4n2_3.pdf

Ayeduso, A.O.( 1997) Perception of Entrepreneurship by Vocational Education Students of Kontagora, Journal of Education, 3 (1), 14.

Barnabas P.A \& Darkwa, F.S. (2007). Distance learning Education as Women empowerment strategy in Nigeria. International Journal of Research Education, 1 (2).

Bamkole P (2007). The Entrepreneurship Challenge in Nigeria Retrieved from http://knowledge.wharton.open.edu/article.cfm?articleid=/675.

Bello, G.B. (2010). Assessment of Government Initiatives on Entrepreneurship Development and Poverty Alleviation in Nigeria, Journal of Finance and Accounting Research, 2 (2).

Bukar, G.M. \&Timothy, Y. A.(2013). Impact of Polytechnic Education on Entrepreneurship Development in Nigeria, Academic Journal of Interdisciplinary Studies, 2(7), 113 - 123.

Cresswell, W.J. (2003). Research Design: Qualitative Quantitative and Mixed Methods Approaches 2nd Ed. Thousand Oaks: Sage Publications.

Dantani SI, I (2014). Entrepreneurship Education as a Tool for Job Creation and National Development. In Proceedings of the $2^{\text {nd }}$ International Conference of the School of Technology Education, Federal University of Technology, Minna with the theme: Minna 12-15 October.

Department of Library, Archival and Information Studies (2006). University of Ibadan: Department of Library, Archival and Information Studies, Master Degree Programmes Prospectus. Ibadan: The Head of Department's Office.

Dickson, P.H. \&Solomon, G. T. (2008). Weaver, Entrepreneurial selection and success: Does Education matter?, Journal of Small Business and Enterprise Development, 15 (2), 239 258.

Ekoja, I.I.\& Odu, A.O. (2016).Developing and implementing entrepreneurship curriculum in Nigerian library and information science programmes. International Journal of Library and Information Science, 8(6), 48-53.

Enactus Nigeria (2014). Lagos, Nigeria-Non-Profit Organisation/Facebook. Retrieved from http://www.actioncoach.com 
Etim, F.E.E . (2002). Integrating Information Handling skills into the Curriculum; a panacea for education reforms in secondary schools in Nigeria. Nigerian Libraries, 36 (1), 26 - 27.

Fakuade, D. (2015). Obama's Global Entrepreneurship Summit. Retrieved from http: the nationonlineng.neton, 12thJuly, 2015.

Gibbs, H.J.(2011) Exciting Entrepreneurship Education. Retrieved from www.acteonline.org/members/techniqueson27thJuly,2011.

Igbeka JU (2008). Entrepreneurship in Library and Information Scienes. Ibadan: Stirling-Horden Isa AO, Uzuegbu CP, Nwosu MC.- Eds (2014). Entrepreneurship Studies and Practices in Library and Information Science. Umuahia: Zeh Communications.

Igbo, C.A.( 2005). Towards inculcating Entrepreneurship Skill in Senior Secondary School Home Economic Students. Journal of Home Economic Research Association 1(1), 14 15.

Lunenburg FC (2011).Theorizing about curriculum: Conceptions and definitions. Int. J. Sch. Acad. Intellect. Divers. 13(1):1-6.

Mohammed, Z. (2003). Library and Information Science Education in Nigeria. Lagos: Nigeria Library Association, $69-82$.

Musa, A.(2009) Critical Assessment of Government Initiatives of Entrepreneurship Development and Poverty Eradication. A Case study of NEEDs. Masters Thesis. Bayero University, Kano, MBA.

Nadozie, C.O., Akanwa P.C and. Nnadozie, C.D. (2013). Aspirations of Nigerian Para Professional Interdisciplinary Studies, 2 (5), 149 - 161.

National Universities Commission (2007). Benchmark Minimum Academic Standards for Undergraduate Programmes in Nigerian Universities. Abuja: NUC.

University of Ilorin (2014). Department of Library and Information Science. LIS 402:

Entrepreneurship in Information. Available at:http://unilorin.edu.ng/courseware/lis.

Wasagu MA (2000). Introduction to curriculum studies. In Junaid MI, Salami AA, Maitafsir, 
MG.- (Eds). Reading in Education, volume. I. Sokoto: Educational Foundation Unit.

Ray, D.( 1998). Entrepreneurship and Economic Development. New York: Harper and Row.

Sinha M.K., Pandey, B.K.(2014). Status of Job opportunities and Employment in Library and Information Science Professionals in India: An analysis of Job advertisement.Journal of Humanities and social Science, 19(1), 79-93.

Sule, M.N. (2004). Sociology of Education in Perspectives Jos: Deka Publishers.

Tyonum, N.M. \& Ezeogu, P.M. (2015). Library and Education: Panacea for sustainable Development in Nigeria. Asian Journal of Information Science and Technology, 5 (2), 28 -30 .

Vincett, P.S. \& Farlow, S. (2008). Start a business: an experiment on education through entrepreneurship. Journal of Small Business and Enterprise Development, 15 (2), 274 -

\section{About the authors:}

\section{Gideon A. Babalola PhD}

Department of Library and Information Technology,

Federal University of Technology Minna, Niger State, Nigeria gaboft7r7@gmail.com g.babalola@futminna.edu.ng

\section{Saba Mohammed Adamu}

University Library Services,

Federal University of Technology Minna, Niger State, Nigeria mohd.adamu@futminna.edu.ng

\section{Kingsley Olawale Aji}

College Library Services

College of Education, FCT, Zuba, Abuja

kingsola4u2003@gmail.com

\section{Fati Abubakar}

University Library Services,

Federal University ofTechnology, Minna, Niger State. Nigeria

\section{Musa Imam Shekarau}

University Library Services,

Federal University of Technology, Minna, Niger State. Nigeria musa.imam@futminna.edu.ng 